\title{
Faktor yang Memengaruhi Kadar NT-proBNP pada Anak dengan PJB Pirau Kiri ke Kanan yang Mengalami Gagal Jantung
}

\author{
Domiko Widyanto, Agus Priyatno, Moedrik Tamam \\ Bagian Ilmu Kesehatan Anak Fakultas Kedokteran Universitas Diponegoro/RSUP dr. Kariadi, Semarang
}

\begin{abstract}
Latar belakang. Amino terminal pro-brain natriuretic peptide (NT-proBNP) merupakan neurohormon jantung yang dikeluarkan sebagai respon terhadap beban tekanan dan volume yang berlebihan pada gagal jantung. Secara teori, faktor yang memengaruhi kadar NT-proBNP di antaranya anemia, frekuensi ISPA sering, dan diameter defek besar.

Tujuan. Membuktikan bahwa anemia, frekuensi ISPA sering, dan diameter defek besar sebagai faktor yang dapat memengaruhi kadar NT-proBNP pada anak dengan PJB pirau kiri ke kanan yang mengalami gagal jantung.

Metode. Penelitian kasus kontrol, subjek 50 anak PJB pirau kiri ke kanan yang mengalami gagal jantung di RSUP dr. Kariadi, terdiri atas 25 anak dengan kadar NT-proBNP di atas cut off point sebagai kasus dan 25 anak di bawah cut off point sebagai kontrol. Kadar NT-proBNP dianalisis dengan metode ELISA, sedangkan uji Mann-Whitney untuk perbedaan kadar NT-proBNP masing-masing kelompok.

Hasil. Kelompok kasus didapatkan rentang usia 2-91 bulan (median 25 bulan), 16 (53,3\%) perempuan, 21 (84\%) diameter defek besar, dan 19 (76\%) malnutrisi. Pada kelompok kontrol didapatkan rentang usia 2-121 bulan (median 35 bulan), 17 (65,4\%) perempuan, 13(52\%) diameter defek besar, dan 14(56\%) malnutrisi. Frekuensi ISPA sering dan diameter defek merupakan faktor risiko peningkatan kadar NT-proBNP $(\mathrm{OR}=3,43$; $\mathrm{p}=0,041$; IK95\%: 1,26-11,47) dan (OR=4,846; $\mathrm{p}=0,015 ; \mathrm{IK} 95 \%: 1,287-18,25)$. Anemia bukan merupakan faktor risiko (OR=1,0; $\mathrm{p}=1,00 ;$ IK95\%:0,25-3,99).

Kesimpulan. Frekuensi ISPA sering dan diameter defek besar merupakan faktor risiko peningkatan kadar NT-proBNP pada anak dengan PJB pirau kiri ke kanan yang mengalami gagal jantung, sedangkan anemia bukan merupakan suatu faktor risiko. Sari Pediatri 2015;17(3):216-21.
\end{abstract}

Kata kunci: gagal jantung, kadar NT-proBNP, PJB pirau kiri ke kanan, ISPA, anemia

\section{Factors that Influence Level of NT-ProBNP in Children with Congenital Heart Disease with Left to Right Shunt and Heart Failure}

Domiko Widyanto, Agus Priyatno, Moedrik Tamam

Background. Amino terminal pro-brain natriuretic peptide (NT-proBNP) is a cardiac neurohormone which is released as a response to the excessive pressure and volume load in heart failure. Theoritically, there are some factors influence the level of NT-proBNP such as anemia, frequent upper respiratory tract infection and the diameter size of large defect.

Objective. To determine anemia, frequent upper respiratory tract infection and the diameter size of large defect as the factors that influence the level of NT -pro BNP in children with left to right shunt due to congenital heart disease and heart failure.

Methods. Case control study with 50 children with left to right shunt due to congenital heart disease and heart failure hospitalized at dr. Kariadi Hospital Semarang Indonesia, consist of 25 children with left to right shunt due to congenital heart disease and heart failure with level of NT-proBNP higher than cut off point as cases and 25 children with the level of NT pro-BNP lower than cut off point as control. The level of NT-proBNP was examined by ELISA method. MannWhitney test was performed to analysis the difference of the level of NT-proBNP between groups.

Result. In case group revealed that has range of age between 2-91 months (median 25 months ), 16(53,3\%) of them were female, $21(84 \%)$ had large defect diameter and $19(76 \%)$ of them had malnutrition. In control group range of age was 2-121 months (median 35 months ), 17(65,4\%) were female, 13(52\%) had large defect diameter and $14(56 \%)$ of them had malnutrition. Frequent upper respiratory infection and large diameter size of defect were the risk for increased level of NT pro-BNP in children with left to right shunt due to congenital heart disease and heart failure $(\mathrm{OR}=3,43, \mathrm{p}=0,041,95 \% \mathrm{CI}=1,26-11,47)$ and $(\mathrm{OR}=4,846, \mathrm{p}=0,015,95 \% \mathrm{CI}=1,287-18,25)$. Anemia was not a risk factor $(\mathrm{OR}=1,0, \mathrm{p}=1,00,95 \% \mathrm{CI}=0,25-3,99)$.

Conclusion. Frequent upper respiratory infection and large defect diameter were the risk for increasing the level of NT pro-BNP in children with left to right shunt congenital heart disease and heart failure but anemia was not a risk factor. Sari Pediatri 2015;17(3):216-21.

Keywords: heart failure, level of NT-proBNP, congenital heart disease, left to right shunt, upper respiratory tract infection

Alamat korespondensi: Dr. Domiko Widyanto. Bagian Ilmu Kesehatan Anak Fakultas Kedokteran Universitas Diponegoro/RSUP dr. Kariadi. Jl. Dr. Soetomo, Semarang. Tel.+6224-8442266,8414296 No.16-18. E-mail:domiko_widyanto@idai.or.id 
$\mathrm{P}$ enyakit jantung bawaan (PJB) merupakan kelainan kongenital paling umum dan jenis penyakit jantung terbanyak pada anak. Ditandai dengan adanya kelainan struktur jantung atau fungsi sirkulasi jantung yang dibawa sejak lahir akibat adanya gangguan atau kegagalan perkembangan struktur jantung pada fase awal perkembangan janin. ${ }^{1}$ Terdapat dua golongan besar $\mathrm{PJB}$, tipe asianotik merupakan bagian terbesar dari seluruh penyakit jantung bawaan dibandingkan dengan lainnya terutama lesi dengan pirau, seperti defek septum ventrikel (DSV), defek septum atrium (DSA), dan duktus arteriousus persisten (DAP). Manifestasi klinisnya sangat bervariasi, dari yang asimptomatik sampai simptomatik seperti kesulitan mengisap susu, sesak nafas, sering terserang infeksi paru, gagal tumbuh kembang hingga gagal jantung kongestif. Gagal jantung pada anak dengan PJB ini disebabkan gangguan pompa jantung, kelainan hemodinamik pirau kiri ke kanan, oversirkulasi paru, dan beban volume yang berlebihan. ${ }^{2}$

Pada keadaan gagal jantung, terjadi kerusakan pada miokardium yang menyebabkan pelepasan sitokin proinflamasi. ${ }^{3}$ Terjadi hipoperfusi pada miokardium yang rusak karena penurunan curah jantung. Hal ini dapat mengaktifkan monosit untuk mengeluarkan sitokin serupa yang dapat merusak miokardium lain. Miokardium yang mengalami "stress" mengeluarkan natriuretic peptides, yang dapat memperbaiki sirkulasi. ${ }^{4}$ $N$ Terminal pro-B type Natriuretic Peptide (NT-proBNP) atau Amino-terminal proBNP merupakan produk hasil pemecahan dari suatu prohormon, yaitu pro-BNP. Peptida ini meningkat saat bayi baru lahir, yaitu pada minggu pertama kehidupan, kemudian menurun pada dewasa normal. Sel otot jantung menghasilkan BNP, terutama ventrikel kiri dan atrium, dilepaskan sebagai respon terhadap dilatasi ventrikel dan beban tekanan berlebihan pada keadaan tertentu terutama pada gagal jantung. ${ }^{5}$ Regulasi BNP berada pada tingkat ekspresi gen, tidak disimpan pada kardiomiosit, berperan dalam vasodilatasi, meningkatkan natriuresis dan diuresis, inhibisi sisten daraf simpatis dan beberapa sistem hormon seperti sistem renin-angiotensin-aldosteron. ${ }^{6}$ Waktu paruh yang lebih cepat dimiliki oleh BNP (sekitar 22 menit) dibandingkan NT-proBNP (1-2 jam), serta lebih stabil selama 24 jam pada suhu $20^{\circ} \mathrm{C}$ dan tidak dipengaruhi oleh aktivitas dan posisi pasien saat pengambilan. ${ }^{7}$ Salah satu manfaat NT-proBNP pada anak adalah marker tersebut dapat membedakan sesak nafas yang disebabkan oleh penyakit paru atau merupakan gejala dari gagal jantung kongestif, selain juga dapat digunakan sebagai evaluasi pengobatan gagal jantung.

Terdapat keadaan yang dapat memengaruhi kadar BNP atau NT-proBNP pada pasien yang mengalami gagal jantung, antara lain usia, body mass index (BMI), jenis kelamin maupun terhadap kondisi penyakit tertentu seperti keadaan anemia, emboli paru, hipertensi pulmonal, gagal ginjal, sepsis. Beberapa penelitian berbeda menyebutkan faktor lain yang dapat menyebabkan perbedaan kadar NT-proBNP, antara lain infeksi saluran pernafasan akut (ISPA) bawah berulang, fungsi tiroid, fungsi hati, dan gangguan ketidakseimbangan elektrolit.

Episode ISPA, terutama bagian bawah, anemia, dan diameter defek merupakan kondisi yang sering ditemukan pada anak dengan PJB yang dapat memengaruhi kadar NT-proBNP. Tujuan penelitian ini adalah untuk membuktikan apakah anemia, frekuensi ISPA sering dan diameter defek besar merupakan faktor yang dapat memengaruhi kadar $N$-terminal Pro-Brain Natriuretic pada anak dengan PJB pirau kiri ke kanan yang mengalami gagal jantung.

\section{Metode}

Desain penelitian observasional kasus kontrol dilakukan di RSUP dr. Kariadi Semarang selama bulan Agustus sampai Desember 2014. Subjek penelitian adalah semua anak usia 2 sampai dengan 168 bulan yang datang berobat di poliklinik anak dan ruang rawat inap unit pelayanan jantung (UPJ) anak yang didiagnosis PJB pirau kiri ke kanan yang mengalami gagal jantung berdasarkan anamnesis, pemeriksaan fisik, elektrokardiografi, dan ekokardiografi yang mempunyai kadar NT-proBNP di atas normal.

Kriteria inklusi kasus adalah anak dengan PJB pirau kiri ke kanan yang belum menjalani operasi jantung, memiliki kadar NT-proBNP di atas normal dan mendapat persetujuan dari orangtua/wali agar dapat dikutsertakan dalam penelitian. Kriteria eksklusi adalah menderita sepsis, kelainan ginjal, sindrom Down, dan keadaan syok.

Jumlah subjek dihitung dengan rumus besar sampel untuk penelitian kasus kontrol. Nilai kesalahan tipe I ditetapkan $5 \%(\alpha=0,05)$, tipe II $20 \%(\beta=0,2)$, dan power penelitian $80 \%$. Diperoleh jumlah subjek 
penelitian minimal 50 anak. Kelompok kontrol ditetapkan 1:1 dengan kelompok kasus. Data dikumpulkan dengan kuisioner yang dilakukan pada orang tua/wali, dan melakukan pemeriksaan lengkap pada pasien (anamnesis, pemeriksaan fisik, radiologis, elektrokardiografi, dan ekokardiografi).

Data dianalisis dengan menggunakan uji $\chi^{2}$ untuk membandingkan distribusi frekuensi dan proporsi variabel faktor risiko antara kelompok kasus dengan kelompok kontrol. Uji Mann-Whitney digunakan untuk membandingkan umur kelompok kasus dengan kelompok kontrol oleh karena berdistribusi tidak normal. Besaran risiko terhadap kejadian IRA bawah dinyatakan sebagai nilai rasio Odd (Odds ratio $=\mathrm{OR})$ yang diperoleh dari analisis bivariat (crude OR) dan multivariat (adjusted OR). Analisis multivariat menggunakan uji regresi logistik ganda. Nilai $\mathrm{p}<0,05$ dianggap bermakna dengan 95\% interval kepercayaan. Pengolahan dan analisis data dilakukan dengan program SPSS for Windows 15.5.

\section{Hasil}

Penelitian melibatkan 25 subjek pada kasus dan 25 sebagai kontrol. Rerata umur subjek penelitian 25 (2-91) bulan. Karakteristik subjek penelitian pada kelompok kasus dan kontrol tertera pada Tabel 1. Dari 50 subjek didapatkan $58 \%$ berjenis kelamin perempuan dan $42 \%$ laki-laki, nilai tengah usia, termuda, dan tertua berturut-turut adalah 28,2 , dan 121 bulan. Rerata kadar Hb 11,6 g\%, sedangkan rerata kadar NT-proBNP adalah 414,8 pg/mL dengan kadar minimum adalah 4,68 pg/mL dan kadar maksimum adalah $3000 \mathrm{pg} / \mathrm{mL}$. Status gizi didapatkan $66 \%$ mengalami malnutrisi dan 34\% dengan gizi baik.

Hasil uji statistik menunjukkan bahwa ISPA sering merupakan faktor risiko peningkatan kadar NTproBNP pada anak pasien PJB pirau kiri ke kanan yang mengalami gagal jantung dengan $\mathrm{OR}=3,43(\mathrm{p}=0,041$; IK95\%:1,26-11,47). Ukuran besar merupakan faktor risiko peningkatan kadar NT-proBNP pada anak pasien

Tabel 1. Karakteristik demografi subyek penelitian

\begin{tabular}{|c|c|c|c|}
\hline Karakteristik & Kasus $(\mathrm{N}=25)$ & Kontrol $(\mathrm{N}=25)$ & $\mathrm{p}$ \\
\hline Usia (bulan) & $25(2-91)$ & $35(2-121)$ & $0,415^{£}$ \\
\hline \multicolumn{4}{|l|}{ Jenis kelamin (\%) } \\
\hline Laki-laki & $13(46,7)$ & $8(34,6)$ & \multirow[t]{2}{*}{$0,152^{¥}$} \\
\hline Perempuan & $12(53,3)$ & $17(65,4)$ & \\
\hline \multicolumn{4}{|l|}{ Diameter Defek (\%) } \\
\hline Kecil-sedang & $4(16)$ & $12(48)$ & \multirow[t]{2}{*}{$0,015^{¥}$} \\
\hline Besar & $21(84)$ & $13(52)$ & \\
\hline \multicolumn{4}{|l|}{ Status gizi (\%) } \\
\hline Gizi baik & $6(24)$ & $11(44)$ & \multirow[t]{2}{*}{0,136} \\
\hline Malnutrisi & $19(76)$ & $14(56)$ & \\
\hline Kadar $\mathrm{Hb}$, rerata $\pm \mathrm{SB}(\mathrm{g} \%)$ & $11,75 \pm 1,46$ & $11,49 \pm 1,19$ & $0,507^{\beta}$ \\
\hline Kadar NT-proBNP, rerata (min-max) (pg/mL) & $1497(152,65-3000)$ & $88,28(4,68-871,9)$ & $0,000^{£}$ \\
\hline
\end{tabular}

Tabel 2. Proporsi frekuensi ISPA, diameter defek, dan anemia berdasarkan kadar NT-proBNP

\begin{tabular}{|c|c|c|c|c|c|}
\hline Variabel & NT-proBNP>normal & NT-proBNP $\leq$ normal & OR & $\mathrm{p}$ & IK95\% \\
\hline \multicolumn{6}{|l|}{ Frekuensi ISPA } \\
\hline Sering & 13 & 6 & \multirow{2}{*}{3,43} & \multirow{2}{*}{0,041} & \multirow{2}{*}{$1,026-11,476$} \\
\hline Jarang & 12 & 19 & & & \\
\hline \multicolumn{6}{|l|}{ Diameter defek } \\
\hline Kecil-sedang & 4 & 12 & \multirow{2}{*}{4,846} & \multirow{2}{*}{0,015} & \multirow{2}{*}{$1,287-18,255$} \\
\hline Besar & 21 & 13 & & & \\
\hline \multicolumn{6}{|l|}{ Kadar $\mathrm{Hb}$} \\
\hline Anemia & 5 & 5 & \multirow{2}{*}{1,0} & \multirow{2}{*}{1,00} & \multirow{2}{*}{$0,25-3,99$} \\
\hline Tidak Anemia & 20 & 20 & & & \\
\hline
\end{tabular}


PJB pirau kiri ke kanan dengan gagal jantung dengan $\mathrm{OR}=4,846(\mathrm{p}=0,015 ; \mathrm{IK} 95 \%: 1,287-18,25)$. Anemia bukan merupakan faktor risiko peningkatan kadar NT-proBNP dengan OR=1,0 ( $\mathrm{p}=1,00$, IK95\%:0,25$3,99)$ seperti tertera pada Tabel 2. Hasil penelitian menunjukkan PJB pirau kiri ke kanan yang mengalami gagal jantung adalah DSV 52\%, diikuti DAP 20\%, DSV dan DSA $18 \%$, serta DSA (10\%).

\section{Pembahasan}

Tidak terdapat perbedaan usia antara kelompok pasien PJB pirau kiri ke kanan dengan gagal jantung yang mempunyai kadar NT-proBNP di atas cut off point dan di bawah cut off point. Hal tersebut mungkin disebabkan karena klinis dan pemeriksaan fisik kelainan PJB sudah dapat ditemukan pada anak berusia lebih dari 6 minggu. Hasil ini sesuai dengan sebagian besar penelitian yang menyebutkan bahwa insiden gagal jantung pada PJB terjadi pada usia kurang dari 1 tahun. Laporan penelitian Massin $\mathrm{dkk}^{8}$ menyebutkan bahwa 58,1\% kejadian gagal jantung terjadi selama 1 tahun pertama kehidupan. Bahkan, Sommers $\mathrm{dkk}^{9}$ melaporkan angka lebih besar, yaitu $70,6 \%$ anak dengan gagal jantung terjadi selama 1 tahun kehidupan.

Defek dengan ukuran besar merupakan faktor risiko peningkatan kadar NT-proBNP. Sebagian besar anak dengan PJB pirau kiri ke kanan yang mengalami gagal jantung mempunyai diameter defek yang besar. Besar diameter defek pada PJB mempunyai definisi tersendiri, dikatakan kecil pada DSV dan DAP bila diameter diameter defek 0-3 mm saat lahir atau defek $<1 / 3$ diameter aorta, sedang bila diameter defek $3-5 \mathrm{~mm}$ saat lahir atau defek antara 1/3-2/3 diameter aorta, dan besar bila diameter defek $>5 \mathrm{~mm}$ saat lahir atau defek mendekati ukuran aorta. Sementara pada DSA dengan diameter kecil bila diameter kurang dari $6 \mathrm{~mm}$, sedang bila diameter $6 \mathrm{~mm}$ hingga $12 \mathrm{~mm}$, dan besar bila diameter lebih dari atau sama dengan $12 \mathrm{~mm}$.

Anak PJB pirau kiri ke kanan dengan diameter defek besar dapat mengakibatkan beban volume yang berlebihan sehingga pada ventrikel kiri yang mengalami dilatasi tersebut menyebabkan keadaan afterload yang meningkat. Selain itu, defek yang besar juga dapat menyebabkan terjadinya ISPA berulang sehingga menyebabkan kadar prohormon meningkat. Laporan penelitian Elsharawy $\mathrm{dkk}^{10}$ bahwa anak yang mengalami DSV didapatkan peningkatan kadar NTproBNP yang berbanding lurus dengan ukuran defek. Penelitian di Finlandia menyebutkan bahwa kadar ANP mempunyai hubungan dengan besar ukuran defek pada pasien anak dengan DSA dan kadar tersebut turun setelah dikoreksi dengan penutupan defek. ${ }^{11}$ Namun, laporan penelitian $\mathrm{Uz} \mathrm{dkk}^{12}$ menyebutkan tidak terdapat hubungan antara besar ukuran defek DSA dengan kadar NT-proBNP.

Frekuensi ISPA yang sering merupakan faktor risiko peningkatan kadar NT-proBNP. Infeksi sendiri merupakan faktor yang dapat memengaruhi kadar NT-proBNP. Penelitian di Yunani menyebutkan bahwa infeksi dapat menyebabkan peningkatan kadar NTproBNP, 35,7\% di antaranya disebabkan oleh infeksi saluran pernafasan. ${ }^{13}$ Laporan penelitianYetkin $\mathrm{dkk}^{14}$ menyebutkan adanya peningkatan kadar BNP pada penderita dewasa dengan pneumonia dibandingkan dengan orang kontrol normal. Anak PJB seringkali mengalami infeksi saluran napas dan bila terkena lebih lama sembuh dibanding anak yang normal, gagal jantung memperburuk keadaan tersebut. Nir $\mathrm{dkk}^{15}$ melaporkan peningkatan kadar NT-proBNP pada anak ISPA dengan gagal jantung dibanding dengan tanpa gagal jantung. Faktor yang dianggap menyebabkan lamanya infeksi tersebut adalah kompresi bronkus besar oleh atrium kiri atau arteri pulmonalis yang membesar akibat hipertensi pulmonal, terjadinya atelektasis atau edema paru akibat hiperperfusi paru, hipoksemia pulmonal dan hipoplasia jalan napas. Hal tersebut sesuai dengan laporan penelitian Yang ${ }^{16}$ yang menyebutkan bahwa pasien dengan pneumonia dan gagal jantung mempunyai kadar NT-proBNP yang lebih tinggi dibandingkan dengan pasien yang hanya mengalami gagal jantung atau pneumonia sendiri.

Anemia bukan merupakan faktor risiko peningkatan kadar NT-proBNP pada anak pasien PJB pirau kiri ke kanan dengan gagal jantung. Sesuai dengan laporan penelitian Wu dkk ${ }^{17}$ yang mengatakan bahwa tidak didapatkan hubungan antara nilai $\mathrm{Hb}$ dalam meningkatkan kadar NT-proBNP pada pasien dewasa dengan gagal jantung. Namun, Desai $\mathrm{dkk}^{18}$ melaporkan bahwa tiap penurunan $1 \mathrm{~g} / \mathrm{dL}$ kadar hemoglobin meningkatkan 20\% lebih banyak kadar NT-proBNP. Toblli dkk juga melaporkan penurunan kadar NTproBNP pada pasien yang mengalami anemia dan gagal jantung setelah diberikan zat besi secara intravena. Hal tersebut disebabkan karena pada keadaan anemia pada gagal jantung dapat mengaktifkan sistem renin 
angiotensin aldosteron, hiperaktivitas dari sistem saraf simpatik atau kapasitas angkut oksigen menjadi turun sehingga kerja jantung meningkat. Keadaan anemia juga meningkatkan volume plasma yang akan memperparah gagal jantung. Selain itu, adanya penyakit penyerta juga menyebabkan peningkatan kadar prohormon ini.

Penelitian kami mempunyai beberapa keterbatasan, antara lain episode frekuensi ISPA sering adalah gabungan dari episode ISPA atas dan bawah sehingga tidak dapat ditentukan apakah dari masing-masing satu dari jenis ISPA tersebut merupakan faktor risiko yang dapat memengaruhi kadar NT-proBNP. Selain itu, sebagian besar subjek penelitian memiliki lebih dari satu faktor risiko yang dapat memengaruhi kadar NT-proBNP sehingga peningkatan kadar NT-proBNP mungkin dapat disebabkan oleh faktor risiko lainnya. Disfungsi ginjal merupakan penyebab utama anemia pada pasien gagal jantung yang diperantarai oleh defisiensi produksi eritropoetin di ginjal. Laporan penelitian Hogenhuis dkk ${ }^{19}$ terhadap penderita gagal jantung mendapatkan bahwa anemia secara independen memengaruhi keparahan gagal jantung. Keparahan gagal jantung berkorelasi positif dengan kadar NT-proBNP, tetapi $73 \%$ pasien gagal jantung yang mengalami anemia juga mengalami gagal ginjal. Risiko anemia pada PJB juga akibat asupan makanan yang kurang. Haryanto ${ }^{20}$ melaporkan bahwa 33,8\% anak PJB asianotik mengalami anemia dan PJB asianotik merupakan faktor risiko 5,4 kali kejadian anemia.

Tidak didapatkan perbedaan status gizi pada kelompok pasien PJB pirau kiri ke kanan yang mengalami gagal jantung serta mempunyai kadar NTproBNP di atas cutoff point dan di bawah cutoff point. Tokel $\mathrm{dkk}^{21}$ melaporkan bahwa 46\% PJB asianotik termasuk DSV mengalami malnutrisi. Selain itu, Kohr $\mathrm{dkk}^{22}$ juga melaporkan ISPA yang berulang dapat menyebabkan anoreksia dan menyebabkan gangguan status gizi. Sementara laporan penelitian Nevo $\mathrm{dkk}^{23}$ dengan subjek orang dewasa mendapatkan adanya korelasi negatif antara kadar NT-proBNP dengan berat badan. Hal tersebut disebabkan karena reseptor clearence dari NT-proBNP telah di isolasi pada jaringan lemak manusia. Frankenstein $\mathrm{dkk}^{24} \mathrm{juga}$ melaporkan hubungan terbalik antara BMI dengan kadar NT-proBNP, walaupun bukan dalam keadaan gagal jantung. Laporan penelitian Baghdady $\mathrm{dkk}^{25}$ mendapatkan hubungan antara kadar NT-proBNP dengan gagal tumbuh pada anak yang mengalami DSV dan gagal jantung berat, didapatkan peningkatan kadar NT-proBNP pada anak dengan DSV dan gagal jantung dengan berat badan yang rendah.

\section{Kesimpulan}

Frekuensi ISPA sering dan ukuran defek yang besar merupakan keadaan yang dapat meningkatkan risiko peningkatan kadar NT-proBNP pada anak dengan PJB pirau kiri ke kanan yang mengalami gagal jantung. Sementara anemia ternyata bukan merupakan faktor risiko dalam peningkatan kadar NT-proBNP pada anak dengan PJB pirau kiri ke kanan yang mengalami gagal jantung. Diperlukan perhatian lebih pada pasien PJB pirau kiri ke kanan yang mengalami gagal jantung yang memiliki ukuran defek yang besar dan frekuensi ISPA yang sering sehingga pengelolaan gagal jantung menjadi lebih optimal. Namun demikian, NT-proBNP sangat berguna dalam menegakkan diagnosis gagal jantung selain pemeriksaan ekokardiografi yang telah digunakan selama ini.

\section{Daftar pustaka}

1. Sastroasmoro S, Madiyono B. Epidemiologi dan etiologi penyakit jantung bawaan. Dalam: Sastroasmoro S, Madiyono B. Buku ajar Kardiologi Anak. Jakarta: Bina Rupa Aksara;1994.h.165-7.

2. Bernstein D. Penyakit Jantung Kongenital Asianotik. Dalam: Nelson WE, Behrman RE, Kliegman R, Arvin AM, penyunting. Nelson Ilmu Kesehatan Anak. Edisi ke15. Philadelphia: Saunders Company; 1999:h.1571-83.

3. Park MK, Salamat M. Congenital Heart Defects. Dalam: Merritt J, penyunting. The pediatric cardiology handbook.Edisi ke-4. Philadelphia: Mosby Elsevier; 2010.h.93-110.

4. Hsu DT, Pearson GD. Heart Failure in Children: Part I: History, Etiology, and Pathophysiology. Circ Heart Fail 2009;2:63-70.

5. Hsu D. Chronic heart failure in congenital heart disease. Dalam: Shaddy R, Wernovsky G, penyunting. Pediatric heart failure. USA: Taylor \& Francis Group; 2005:h.56779.

6. Colucci W, Braunwald E. Chapter 16 - Pathophysiology of heart failure. Dalam: Braunwald, penyunting. Heart 
disease: a textbook of cardiovascular medicine. Edisi ke-6. Philadelphia: W.B.Saunders Company; 2001.h.503-13.

7. Park M. Chapter 12-Left-to-Right Shunt Lesions. Dalam: Pediatric Cardiology for Practitioners. Edisi ke-5. St. Louis: Mosby, Elsevier;2008.

8. Massin MM, Astadicko I, Dessy H. Epidemiology of heart failure in a tertiary pediatric center. Clin Cardiol 2008;31:388-91.

9. Sommers C, Nagel BH, Neudorf U, Schmaltz AA. Congestive heart failure in childhood. An epidemiologic study. Herz 2005;30:652-62.

10. Elsharawy S, Hassan B, Morsy S, Khalifa N. Diagnostic value of $\mathrm{N}$-terminal pro-brain natriuretic peptide levels in pediatric patients with ventricular septal defect. Egyp Heart J 2012:64:241-6.

11. Torfs CP, Christianson RE. Anomalies in Down Syndrome individuals in a large population-based registry.Am J Cardiol 2009:25:223-5.

12. Uz O, Aparcı M, Acar G, Kardesoglu E, Kaplan O, Yiginer O. Association of plasma B-type natriuretic peptide levels with shunt size in young adults with atrial septal defect. Echocardiography 2011;28:243-7.

13. Goritsas C, Fasoulaki M, Paissios N, Giakoumaki E, Alamanos Y, Nikolaou I. Brain natriuretic peptide plasma levels as a marker of prognosis in patients with community-acquired infection. Eur J Emerg Med 2010.17:293-5.

14. Yetkin O, Hacievliyagi SS, Gunen H. Assesment of B-typ natriuretic peptide in patients with pneumonia. Int $\mathrm{J}$ Clin Pract.2008;62:488-91.

15. Nir A, Lindiger A, Rauh M, Oz BB, Laer S, Schwachtgen L, dkk. NT-Pro-B-type Natriuretic Peptide in Infants and Children: Reference Values Based on Combined Data from Four Studies. Pediatr Cardiol (2009) 30:h.3-8.

16. Yang S, Li L, Cao J,Yu H, Xu H. The Differential diagnostic value of serum NT-proBNP in hospitalized patients of heart failure with pneumonia. J Clin Lab Anal 2015;29:37-42.
17. Wu AH, Omland T, Wold Knudsen C, McCord J, Nowak RM, Hollander JE. Relationship of B-type natriuretic peptide and anemia in patients with and without heart failure: a substudy from the breathing not properly (BNP) multinational study. Am J Hematol 2005;80:17480.

18. Desai AS, Kirsten BD, Shlipak MG, Wu AHB, Ali $S$, Whooley MA. Association between anaemia and $\mathrm{N}$-terminal pro-B-type natriuretic peptide (NTproBNP): findings from the heart and soul study. Eur J Heart Failure 2007;886-91.

19. Hogenhuis J, Voors AA, Jaarsma T, Hoes AW, Hillege HL, Kragten JA, dkk. Anemia and renal dysfunction are independenly associated with BNP and NT-proBNP levels in patients with heart failure. Eur J Heart Failure 2007;9:787-94.

20. Hariyanto D. Profil penyakit jantung bawaan di instalasi rawat inap anak RSUP Dr.M.Djamil Padang Januari 2008 - Februari 2011. Sari Pediatri 2012;14:152-7.

21. Tokel K, Azak E, Ayabakan C, Varan B, Aslamaci SA, Mercan S Somatic growth after corrective surgery for congenital heart disease. Turk J Pediat 2010;52:58-67.

22. Kohr LM, Braudis NJ. Growth and nutrition. Dalam: Anderson RH, Baker EJ, Penny D, penyunting. Pediactric cardiology. Edisi ke-3. Philadelphia: Churcill Livingstone;2010.h.1285-98

23. Nevo I, Erlichman M, Algur N, Nir A. N-terminal pro B-type natriuretic peptide levels in infants and children with acute non-cardiac diseases. IMAJ 2011;13:420-4.

24. Frankenstein L, Remppis A, Nelles M, Schaelling B, Schellberg D, Katus H. Relation of N-terminal pro-brain natriuretic peptide levels and their prognostic power in chronic stable heart failure to obesity status. Eur Heart J 2008;29:2634-40.

25. Baghdady Y, Kamel Y, Elwan A, Tohamy K, Hussein $\mathrm{H}$. $\mathrm{N}$-terminal pro-brain natriuretic peptide in decompansated ventricular septal defect. HMJ 2008;2:36-41. 